Available online at http://journal.stkip-andi-matappa.ac.id/index.php/histogram/index

Histogram : Jurnal Pendidikan Matematika 2 (2), 2018, 132-146

\title{
PENGARUH PROFESIONALISME MENGAJAR DAN TINGKAT SOSIAL EKONOMI MELALUI MINAT TERHADAP HASIL BELAJAR STATISTIKA
}

\author{
Rahma Hidayati Darwis \\ IAIN Bone \\ * Corresponding Author. Email: rahma_darwis@yahoo.com \\ Received: 1 September 2018; Revised: 21 September 2018; Accepted: 27 September 2018
}

\begin{abstract}
ABSTRAK
Jenis penelitian ini adalah penelitian ex-post facto yang bersifat kausalitas. Populasi dalam penelitian seluruh Mahasiswa STAIN Watampone Jurusan Syariah Program studi ekonomi Syariah. Teknik pengambilan sampel adalah simple random sampling. Teknik pengumpulan data dilakukan dengan membagikan angket kepada responden yang terbagi tiga yaitu angket profesionalisme mengajar, tingkat sosial ekonomi, dan minat belajar. Analisis data menggunakan teknik analisis statistik deskriptif dan teknik analisis statistik inferensial menggunakan AMOS 20. Hasil yang diperoleh dari analisis statistik deskriptif, untuk profesionalisme mengajar dosen menurut pandangan mahasiswa berada pada kategori tinggi, untuk tingkat sosial ekonomi berada pada kategori sedang, untuk kemampuan minat belajar mahasiswa berada pada kategori tinggi. Sementara hasil yang diperoleh dari analisis statistik inferensial; 1) sekitar 26,8\% variansi hasil belajar mahasiswa pada mata kuliah statistik inferensial dipengaruhi oleh profesionalisme mengajar, tingkat sosial ekonomi dan minat belajar secara bersama-sama. Sehingga masih ada 73,2\% varians hasil belajar mahasiswa yang dijelaskan oleh faktor-faktor lain yang tidak ikut diselidiki dalam penelitian, 2) minat belajar mahasiswa dapat memperkuat pengaruh profesionalisme mengajar dan tingkat sosial ekonomi dalam meningkatkan hasil belajar. Konstribusi profesionalisme mengajar dan tingkat sosial ekonomi terhadap hasil belajar mahasiswa akan semakin besar jika masing-masing variabel profesionalisme mengajar dan tingkat sosial ekonomi disertai dengan minat belajar yang tinggi.
\end{abstract}

Kata kunci: Profesionalisme, tingkat sosial ekonomi, Minat belajar, Hasil Belajar.

How to Cite: Darwis, H., R. (2018). Pengaruh Profesionalisme Mengajar Dan Tingkat Sosial Ekonomi Melalui Minat Terhadap Hasil Belajar Statistika. Histogram: Jurnal Pendidikan Matematika, 2(2), 132-146. doi: http://dx.doi.org/10.31100/histogram.v2i2.227

Permalink/DOI:

http://dx.doi.org/10.31100/histogram.v2i2.227

\section{PENDAHULUAN}

Perkembangan zaman yang semakin modern, terutama pada era globalisasi seperti sekarang ini, menuntut adanya sumber daya manusia yang berkualitas tinggi. Peningkatan kualitas sumber daya manusia merupakan prasyarat mutlak untuk mencapai tujuan pembangunan. Salah satu cara untuk meningkatkan kualitas sumber daya manusia tersebut adalah pendidikan. Pendidikan adalah usaha sadar untuk mengembangkan potensi sumber daya manusia melalui kegiatan pengajaran. UU Sistem Pendidikan Nasional No. 20 tahun

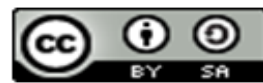




\section{Histogram: Jurnal Pendidikan Matematika, 2 (2), 2018 - 133 Rahma Hidayati Darwis}

2003, menyatakan bahwa tujuan pendidikan nasional adalah mencerdaskan kehidupan bangsa dan mengembangkan manusia Indonesia seutuhnya yaitu manusia yang bertakwa terhadap Tuhan Yang Maha Esa dan berbudi pekerti luhur, memiliki pengetahuan dan keterampilan, kesehatan jasmani dan rohani, kepribadian yang mantap dan mandiri serta tanggung jawab kemasyarakatan dan kebangsaan (UU Sisdiknas, 2003).

Perguruan tinggi mempunyai tujuan yaitu menyiapkan peserta didik menjadi anggota masyarakat yang memiliki kemampuan akademik dan atau profesional yang dapat menerapkan, mengembangkan dan atau memperkaya khasanah ilmu pengetahuan, teknologi dan atau kesenian mengembangkan dan menyebarluaskan ilmu pengetahuan, teknologi atau kesenian serta mengupayakan penggunaannya untuk meningkatkan taraf kehidupan masyarakat dan memperkaya kebudayaan nasional (pasal 2 Peraturan Pemerintah Republik Indonesia Nomor 60 Tahun 2002). Dalam mengembangkan ilmu pengetahuan, teknologi, serta upaya meningkatkan taraf kehidupan masyarakat yang berdaya guna maka perlu mendapatkan pendidikan yang optimal untuk memperoleh hasil belajar yang baik, berdaya guna bagi nusa dan bangsa. Hasil belajar adalah keberhasilan seseorang dalam suatu proses belajar mengajar meliputi 3 aspek yaitu aspek kognitif, afektif, dan psikomotorik (Prasetya, 2001).

Berbagai faktor yang dapat mempengaruhi hasil belajar baik faktor internal maupun eksternal. Dari factor internal salah satunya yang selalu menjadi permasalahan yaitu berupa minat belajar sedangkan faktor eksternal dapat berupa tingkat sosial ekonomi dan profesionalisme Dosen. Variabel-variabel tersebut ada yang saling berinteraksi antara satu dengan yang lainnya dan mungkin ada yang tidak saling berinteraksi, sehingga diperlukan pengetahuan yang memadai untuk mengetahui variabel mana yang lebih berpengaruh terhadap hasil belajar mahasiswa.

Slameto (2003: 108) menyatakan mahasiswa yang memiliki minat terhadap objek tertentu cenderung untuk memberikan perhatian yang lebih besar terhadap objek tersebut. Minat memiliki pengaruh yang signifikan terhadap kegiatan seseorang sebab dengan minat mereka akan melakukan sesuatu yang diminatinya. Oleh karena itu, minat belajar perlu mendapat perhatian khusus dari dosen untuk memudahkan dalam membimbing dan mengarahkan mahasiswa. Sedangkan professional mengajar dosen yang merupakan kemapuan merencanakan pembelajaran, penguasaan terhadap materi, kemampuan mengelola kelas dan melakukan evaluasi penilaian juga berperan penting dalam peningkatan hasil belajar mahasiswa. Dosen yang professional dalam mengajar dapat Copyright (C) 2018, Histogram: Jurnal Pendidikan Matematika ISSN: 2549-6700 (print), ISSN 2549-6719 (online) 
mengembangkan materi dan mampu mengeksplorasi keterampilan mengajarnya, serta menciptakan suasana yang kondusif sehingga akan berimplikasi terhadap kualitas hasil belajar mahasiswa.

Faktor lain yang turut berperan dalam menunjang hasil belajar mahasiswa adalah ketersediaan fasilitas penunjang dalam proses belajar mengajar. Ketersedeian fasilitas penunjang tentu sangat dipengaruhi oleh tingkat sosial ekonomi keluarga, sehingga secara tidak langsung tingkat ekonomi keluarga turut berkonstribusi dalam menentukan hasil belajar mahasiswa. Fenomena tersebut membawa peneliti tertarik mengetahui lebih mendalam mengenai pengaruh Profesionalisme Mengajar, Tingkat Sosial Ekonomi Melalui Minat Mahasiswa terhadap Hasil Belajar Satistika Inferensial di Prodi Ekonomi Syariah STAIN Watampone. Berikut ini disajikan skema penelitian yang dilakukan

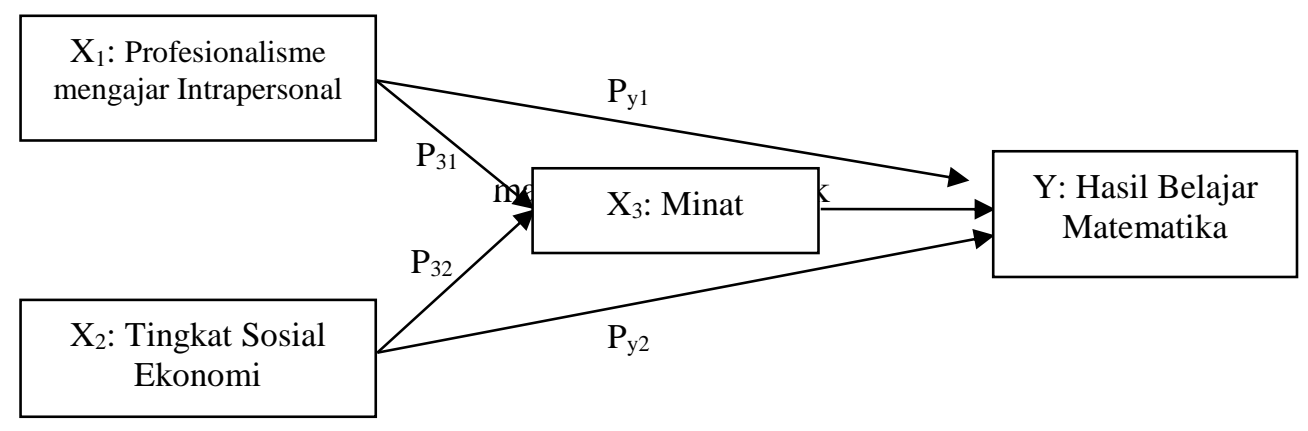

Keterangan: $\quad \mathrm{P}_{31}$ : Garis Korelasi Variabel $\mathrm{X}_{1}$ ke Variabel $\mathrm{X}_{3}$ $\mathrm{P}_{32}$ : Garis Korelasi Variabel $\mathrm{X}_{2}$ ke Variabel $\mathrm{X}_{3}$ $\mathrm{P}_{\mathrm{y} 1}$ : Garis Korelasi Variabel $\mathrm{X}_{1}$ ke Variabel $\mathrm{Y}$ $\mathrm{P}_{\mathrm{y} 1}$ : Garis Korelasi Variabel $\mathrm{X}_{1}$ ke Variabel $\mathrm{Y}$

\section{METODE PENELITIAN}

\section{A. Jenis Penelitian}

Penelitian ini menyelidiki kemungkinan adanya hubungan sebab akibat dengan cara menghitung besar pengaruh beberapa faktor terhadap hasil belajar mahasiswa dalam Statistika Inferensial. Penelitian ini termasuk jenis penelitian ex post facto yaitu metode penelitian yang menunjukkan bahwa perlakuan terhadap variabel bebas telah terjadi sebelumnya, sehingga tidak perlu memberi perlakuan, tinggal melihat efeknya pada variabel terikat. 


\section{B. Variabel Penelitian}

Ditinjau dari tujuannya, penelitian ini merupakan penelitian korelasi. Penelitian korelasi adalah suatu penelitian yang melibatkan tindakan pengumpulan data guna menentukan apakah ada pengaruh dan hubungan atar variabel. Variabel yang diselidiki dalam penelitian ini terbagi dalam dua jenis, yaitu variabel eksogen dan variabel endogen. Variabel-variabel eksogennya adalah profesionalisme mengajar $\left(\mathrm{X}_{1}\right)$, tingkat sosial ekonomi $\left(\mathrm{X}_{2}\right)$, minat mahasiswa $(\mathrm{X} 3)$, sedangkan variabel endogennya adalah hasil belajar Statistika Inferensial (Y)

\section{Lokasi, Populasi dan Sampel}

1. Lokasi Penelitian

Tempat penelitian dilakukan di STAIN Watampoe, Jl. Hos Cokroaminoto, Kelurahan Macanang, Kecamatan Tanete Riattang Barat, Kabupaten Bone pada Mahasiswa Semester V. Penelitian ini akan dilaksanakan pada Semester Ganjil Tahun Ajaran 2017/2018 pada bulan Juli sampai September 2017 dengan jadwal kegiatan yang disajikan pada Lampiran.

2. Populasi dan sampel

Berkenaan dengan penelitian ini, maka yang akan menjadi populasi dalam penelitian adalah seluruh mahasiswa Semester V Ekonomi Syariah tahun ajaran 2017/2018 yang berjumlah 293 siswa yang terbagi dalam 11 kelompok. Selanjutnya akan dipilih sampel penelitian sebanyak 4 kelompok dari 11 kelompok mahasiswa Semester V Ekonomi Syariah sebagai representatif dari populasi penelitian.

\section{Teknik Pengambilan Sampel}

Pada peneletian ini digunakan teknik cluster sampling sebagai teknik pengambilan sampel. Teknik cluster sampling digunakan dengan asumsi distribusi 11 kelompok mahasiswa Ekonomi Syariah bersifat homogen. Dengan kata lain tidak ada kelompok yang lebih unggul dibanding kelompok yang lain sehingga pemilihan 4 kelompok dapat merepresentasikan keseluruhan populasi.

\section{E. Data dan Sumber Data}

Jenis data dalam penelitian ini adalah data primer dan data sekunder sedangkan sumber data dalam penelitian ini diperoleh dari jawaban kuesioner yang dibagikan kepada mahasiswa yang telah mengikuti Matakuliah Statistika Inferensial Semester V Ekonomi Syariah dan Sumber yang diperoleh melalui situs yang dimiliki oleh kampus STAIN Watampone, yaitu www.sisfo.stain-watampone.ac.id. ISSN: 2549-6700 (print), ISSN 2549-6719 (online) 
Data primer dalam penelitian ini berupa: 1) identitas responden, berupa: nama, NIM dan jenis kelamin, dan 2) persepsi responden terhadap profesionalisme mengajar dosen, minat mahasiswa dan tingkat sosial ekonomi. Dalam penelitian ini pengukuran variabel menggunakan skala likert poin 5 dengan klasifikasi sebagai berikut; nilai 1 untuk jawaban Sangat Tidak Setuju (STS), 2 untuk jawaban Tidak Setuju (TS), 3 untuk jawaban Netral (N), 4 untuk jawaban Setuju (S), dan 5 untuk jawaban Sangat Setuju (SS). Sedangkan data sekunder dalam penelitian ini berupa: jumlah Mahasiswa Semester V dan hasil belajar Mahasiswa Semester V yang telah mengikuti matakuliah Statistika Inferensial.

\section{F. Instrumen Penelitian}

Instrumen yang digunakan dalam penelitian ini terdiri dari instrumen minat mahasiswa, instrumen Profesionalisme Mengajar dosen dan instrumen tingkat sosial ekonomi orang tua mahasiswa. Instrumen minat mahasiswa dan professional mengajar dosen yang digunakan dalam penelitian berupa angket dengan 5 alternatif jawaban, sedangkan instrument tingkat ekonomi sosial juga berupa angket dengan 4 alternatif jawaban. Sebelum instrument digunakanan terlebih dahulu dilakukan validasi yakni validasi rasional oleh ahli dan praktisi serta validasi konstruk atau empirik yang diuji cobakan pada mahasiswa YPUP Makassar.

\section{G. Teknik Pengumpulan Data}

Teknik pengumpulan data yang digunakan dalam penelitian ini berupa: metode dokumntasi dan metode angket. Metode dokumentasi dilakukan untuk mendapatkan data yang berguna untuk penelitian seperti jumlah mahasiswa dan hasil belajar Statistika Inferensial tahun ajaran 2016/2017. Sedangkan metode angket digunakan untuk mengumpulkan data mengenai Profesionalisme Mengajar dosen, minat mahasiswa dan tingkat social ekonomi orang tua mahasiswa.

\section{H. Teknik Analisis Data}

Data yang telah diperoleh dianalisis dengan menggunakan teknik analisis statistik, yaitu statistik deskriptif dan statistik inferensial.

\section{Analisis Deskriptif}

Statistik deskriptif memberikan gambaran atau deskripsi suatu data yang dilihat dari nilai rata-rata (mean), median, standar deviasi, nilai maksimum, dan nilai minimum dari data sampel. Analisis ini untuk memberikan gambaran mengenai distribusi dan perilaku data sampel tersebut. 
Selanjutnya, untuk pengkategorian angket digunakan kategori tertentu yang mengacu pada skor rata-rata kategori angket yang diperoleh responden. Penggunaan skor kategori ini digunakan sesuai dengan lima kategori yang dikembangkan dalam skala likert dan digunakan dalam penelitian ini. Adapun kriteria yang dimaksud adalah sebagai berikut:

\begin{tabular}{cc}
\hline Rentang Kategori Skor & Penafsiran \\
\hline $\mathbf{1 , 0 0}-\mathbf{1 , 7 9}$ & sangat tidak baik/Sangat rendah \\
$\mathbf{1 , 8 0}-\mathbf{2 , 5 9}$ & Tidak Baik/Rendah \\
$\mathbf{2 , 6 0}-\mathbf{3 , 3 9}$ & Cukup/Sedang \\
$\mathbf{3 , 4 0}-\mathbf{4 , 1 9}$ & Baik/Tinggi \\
$\mathbf{4 , 2 0}-\mathbf{5 , 0 0}$ & Sangat Baik/Sangat Tinggi \\
\hline
\end{tabular}

Sumber: Sudjana, Tahun: 2001

\section{Analisis Inferensial}

Suatu penelitian membutuhkan analisis data dan interpretasi yang bertujuan menjawab pertanyaan-pertanyaan penelitian dalam rangka mengungkap fenomena sosial tertentu. Analisis data adalah proses penyederhanaan data ke dalam bentuk yang lebih mudah dibaca dan diinterpretasikan. Metode yang dipilih untuk menganalisis data harus sesuai dengan pola penelitian dan variabel yang akan diteliti yaitu analisis jalur. The Structural Equation Modelling (SEM) dari paket software statistik AMOS digunakan dalam model dan pengujian hipotesis.

\section{a. Pengembangan Diagram Alur (Path Diagram)}

Diagram alur akan mempermudah dalam melihat hubungan-hubungan kausal biasanya dinyatakan dalam bentuk persamaan. Dalam model SEM digunakan construk atau factor yang mempunyai pijakan teoritis yang cukup untuk mejelaskan berbagai bentuk hubungan alur sebab akibat dari berbagai konstruk yang digunakan.

\section{b. Uji Asumsi yang Melandasi SEM}

Pemeriksaan asumsi yang melandasi Structural equation Modeling (SEM) dalam penelitian ini meliputi: uji data outlier, Uji normalitas data, uji Kesesuaian Model

(Goodness off it Model), $\chi^{2}$-Chi-square statistic. Tujuan pengujian Chi-square, GFI (Goodness of Fit Index), AGFI (Adjusted Goodness Fit Index, RMSEA (The Root Mean Square Errorof Approximation), CMIN/DF, TLI (Tucker Lewis Index), CFI (Comparative FitIndex), AIC (Aikake Information Criterion). 


\section{III.HASIL DAN PEMBAHASAN}

Pada bagian ini dibahas mengenai gambaran penelitian berdasarkan analisis deskriptif dan gambaran penelitian berdasarkan analisis inferensialnya serta keterkaitan antara teori dengan hasil penelitian.

\section{A. Deskriptif Profesionalisme mengajar}

Salah satu tujuan penelitian ini diantaranya adalah untuk mendeskripsikan faktorfaktor eksternal yang dapat mempengaruhi hasil belajar mahasiswa dalam hal ini salah satunya adalah profesionalisme mengajar. Hasil analisis sebelumnya menunjukkan bahwa tidak ada mahasiswa yang menilai dalam kategori sangat rendah dan rendah, 14 mahasiswa atau $23,33 \%$ yang memberikan penilaian terhadap profesionalisme mengajar dalam kategori sedang, 32 mahasiswa atau 53,34\% yang yang memberikan penilaian dalam kategori tinggi, dan 14 mahasiswa atau 23,33\% yang memberikan penilaian pada kategori sangat tinggi. Sehingga ferekuensi terbanyak berada pada kategori tinggi dan frekuensi terendah berada pada kategori sangat rendah dan rendah. Hal ini menunjukkan bahwa secara umum kemampuan dosen dalam merencanakan, melaksanakan serta mengevaluasi pembelajaran tergolong baik atau tinggi.

\section{B. Deskriptif Tingkat Sosial Ekonomi}

Faktor eksternal lain yang juga dapat mempengaruhi hasil belajar mahasiswa adalah tingkat sosial ekonomi. Dari hasil analisis sebelumnya terdapat 3 mahasiswa atau 5\% yang memiliki tingkat sosial ekonomi tinggi, 28 mahasiswa atau 46,67\% yang memiliki tingkat sosial ekonomi sedang, dan 29 mahasiswa atau 48,33\% yang memiliki tingkat ekonomi rendah. Sehingga ferekuensi terbanyak berada pada kategori rendah dan frekuensi terendah berada pada kategori tinggi. Namun secara umum terlihat bahwa antara mahasiswa yang memiliki tingkat ekonomi sosial rendah dengan mahasiswa yang memiliki tingkat ekonomi sosial sedang hampir sama. Dari keterangan tersebut dapat dikatakan bahwa tingkat sosial ekonomi yang terdiri dari beberapa indikator seperti pendidikan, pendapatan dan kepemilikan berada pada kategori sedang.

\section{Deskriptif Minat Belajar}

Selain faktor-faktor eksternal yang dapat mempengaruhi hasil belajar mahasiswa dalam hal ini profesionalisme mengajar dan tingkat sosial ekonomi juga terdapat faktor internal yakni minat belajar yang dimiliki mahasiswa. Dari hasil analisis diperoleh bahwa tidak mahasiswa yang minat belajarnya berada pada kategori sangat rendah, 3 mahasiswa 
atau 5\% yang memiliki minat belajar berada pada kategori rendah, 15 mahasiswa atau 25\% yang memiliki minat belajar dalam kategori sedang, 27 mahasiswa atau 45\% yang memiliki minat belajar pada kategori tinggi, dan 15 mahasiswa atau 25\% yang berada pada kategori sangat tinggi. Sehingga ferekuensi terbanyak berada pada kategori tinggi dan frekuensi terendah berada pada kategori sangat rendah.

Data tersebut di atas menunjukkan bahwa mata kuliah statistik inferensial memiliki daya tarik yang tinggi bagi mahasiswa Ekonomi Syariah. Dapat juga dikatakan bahwa peserta didik memiliki kecenderungan belajar statistik inferensial yang tinggi.

\section{Deskripsi Hasil Belajar}

Berdasarkan hasil belajar mahasiswa, dapat dikemukakan bahwa hasil analisis data memberikan informasi bahwa hasil belajar mahasiswa pada mata kuluah statistik inferensial berada dalam kategori tinggi. Hal ini dikuatkan dengan hasil penelitian yang menunjukkan bahwa hanya 1 mahasiswa atau 1,67\% yang hasil belajarnya berada pada kategori sangat rendah, 1 mahasiswa atau 1,67\% yang memiliki hasil belajar berada pada kategori rendah, 7 mahasiswa atau 11,66\% yang memiliki hasil belajar dalam kategori sedang, 37 mahasiswa atau 61,67\% yang memiliki hasil belajar pada kategori tinggi, dan 14 mahasiswa atau $23,33 \%$ yang berada pada kategori sangat tinggi. Sehingga ferekuensi terbanyak berada pada kategori tinggi dan frekuensi terendah berada pada kategori sangat rendah.

\section{E. Model struktural faktor internal dan faktor eksternal serta hasil belajar mahasiswa}

Berdasarkan hasil verifikasi model dan hasil-hasil pengujian hipotesis sebagaimana telah dikemukakan di atas, berikut dikemukakan pembahasan terhadap hasil yang diperoleh.

\section{Signifikansi model}

Hasil verifikasi atas model teoritis yang telah dikembangkan dalam kerangka konseptual, pada model tahap awal belum acceptable. Artinya model tersebut kurang fit atau belum dapat diterima dalam menjelaskan kondisi pola profesionalisme mengajar, tingkat ekonomi dan minat belajar terhadap hasil belajar mahasiswa ekonomi syariah STAIN Watampone. Model yang belum acceptable merupakan model yang belum memadai untuk digunakan dalam analisis berikutnya yaitu pengujian hipotesis. Peningkatan model fit dilakukan sehingga indeks overal fitnya dapat memenuhi kriteria kecocokan dan memberikan model tahap final. Hasil tersebut menunjukkan model (model Copyright (C) 2018, Histogram: Jurnal Pendidikan Matematika ISSN: 2549-6700 (print), ISSN 2549-6719 (online) 


\section{Histogram: Jurnal Pendidikan Matematika, 2 (2), 2018 - 140 Rahma Hidayati Darwis}

pengukuran dan model struktural) yang telah memenuhi kriteria kebaikan dan dapat ditetapkan sebagai model struktural yang signifikan dalam menjelaskan keterhubungan faktor internal (minat belajar) dan faktor eksternal (profesionalisme mengajar dan tingkat sosial ekonomi) terhadap hasil belajar mahasiswa ekonomi syariah STAIN Watampone.

2. Model persamaan struktural

Model struktural yang diperoleh dapat memberikan indeks overall fit yang lebih baik (acceptable). Secara matematis, model persamaan struktural dapat disajikan sebagai berikut:

$X_{3}=0,412 X_{1}+0,422 X_{2}+e 1$

$Y=0,335 X_{1}+0,078 X_{2}+0,694 X_{3}+e 2$

di mana

$\mathrm{X}_{1}$ dan $\mathrm{X}_{2}$ berturut-turut adalah profesionalisme mengajar dan tingkat sosial ekonomi,

$\mathrm{X}_{3}$ minat belajar $\mathrm{Y}$ hasil belajar mahasiswa

Persamaan struktural yang diperoleh melalui model tahap final diharapkan dapat menjelaskan kondisi keterhubungan antara profesionalisme mengajar, tingkat sosial ekonomi dan minat belajar terhadap hasil belajar mahasiswa program studi ekonomi syariah STAIN Watampone. Persamaan regresi $\mathrm{Y}=0,335 X_{1}+0,078 X_{2}+0,694 X_{3}+$ $e 2$ dan $R^{2}=0,268$ berarti bahwa sekitar $26,8 \%$ variansi hasil belajar mahasiswa pada mata kuliah statistik dapat dijelaskan oleh profesionalisme mengajar, tingkat sosial ekonomi dan minat belajar secara bersama-sama. Sehingga masih ada 73,2\% varians hasil belajar mahasiswa yang dijelaskan oleh faktor-faktor lain yang tidak ikut diselidiki dalam penelitian ini. Faktor-faktor tersebut yang kemungkinan mengakibatkan belum maksimalnya hasil belajar mahasiswa yang dicapai.

Persamaan regresi $X_{3}=0,412 X_{1}+0,422 X_{2}+e 1$ dan $R^{2}=0,414$ berarti bahwa sekitar 41,4\% variansi minat belajar mahasiswa dapat dijelaskan oleh profesionalisme mengajar dan tingkat sosial ekonomi secara bersama-sama. Sehingga masih ada 58,6\% variansi minat belajar mahasiswa yang dijelaskan oleh faktor-faktor lain yang tidak ikut diselidiki dalam penelitian ini. Faktor-faktor tersebut yang kemungkinan mengakibatkan belum maksimalnya variabel minat belajar mahasiswa yang dicapai.

Model struktural pengaruh faktor-faktor internal-eksternal terhadap hasil belajar mahasiswa pada mata kuliah statistik inferensial tersebut menyatakan bahwa makin baik 


\section{Histogram: Jurnal Pendidikan Matematika, 2 (2), 2018 - 141 Rahma Hidayati Darwis}

faktor eksternal yang diperoleh mahasiswa dan makin tinggi faktor internal yang dimiliki mahasiswa maka semakin tinggi hasil belajar mahasiswa program studi ekonomi syariah STAIN Watampone.

\section{F. Pengaruh faktor-faktor internal-eksternal terhadap hasil belajar mahasiswa}

Hasil penelitian menunjukkan Hybrid model yang acceptable fit, maka diperoleh hasil penelitian yang menunjukkan bahwa profesionalisme mengajar berpengaruh positif dan signifikan terhadap minat belajar mahasiswa. Artinya, semakin tinggi profesionalisme mengajar dosen maka akan semakin berminat mahasiswa belajar. Hal ini terjadi karena profesionalisme mengajar menekankan pada penguasaan pengelolaan proses belajar mengajar yang meliputi prinsip-prinsip mengajar, keterampilan mengelola kelas, keterampilan menilai hasil belajar mahasiswa, penggunaan alat bantu dan keterampilanketerampilan mengajar lainnya. Proses belajar mengajar tersebut dilaksanakan dengan tujuan menumbuhkan dan menciptakan kegiatan mahasiswa agar lebih aktif dalam proses pembelajaran. Keaktifan mahasiswa tersebut secara tidak langsung akan mempengaruhi minat mahasiswa untuk belajar. Sebab membiarkan mahasiswa tidak aktif dalam proses pembelajaran akan melahirkan rasa jenuh dan ketidakbermaknaan belajar sehingga mengurangi minat untuk belajar.

Selain itu untuk meningkatkan minat belajar mahasiswa dosen hendaknya menggunakan metode mengajar yang tepat, efesien dan efektif yakni dengan dilakukannya keterampilan variasi dalam menyampaikan materi dan yang dapat melakukan kegiatankegiatan tersebut adalah dosen yang professional sebagaimana surya (2005) menyatakan bahwa dosen yang profesional akan tercermin dalam pelaksanaan pengabdian tugas-tugas yang ditandai dengan keahlian baik dalam materi maupun metode.

Profesionalisme mengajar dan tingkat sosial ekonomi secara bersama-sama juga memberikan pengaruh yang positif terhadap minat belajar mahasiswa STAIN Watampone program studi ekonomi syariah. Artinya semakin tinggi Profesionalisme mengajar dan tingkat sosial ekonomi maka semakin meningkat minat belajar mahasiswa.

Kehadiran dosen professional tentunya akan berdampak positif terhadap perkembangan mahasiswa, baik dalam pengetahuan maupun dalam keterampilan. Oleh sebab itu, mahasiswa akan antusias dengan apa yang disampaikan oleh dosen yang bertindak sebagai fasilitator dalam proses kegiatan belajar mengajar. Bila hal itu terlaksana dengan baik, maka apa yang disampaikan oleh dosen akan berpengaruh terhadap minat 


\section{Histogram: Jurnal Pendidikan Matematika, 2 (2), 2018 - 142 Rahma Hidayati Darwis}

belajar mahasiswa, sehingga mahasiswa tertarik untuk lebih meningkatkan prestasi belajarnya.

Ketertarikan akan menghasilkan minat belajar pada mahasiswa. Minat itu sendiri dipengaruhi oleh faktor psikis, fisik, dan lingkungan yang ketiganya ini saling melengkapi. Minat menjadi sumber yang kuat untuk suatu aktivitas, karena minat mahasiswa dalam belajarnya bergantung pada kemampuan seorang dosen dalam proses belajar mengajarnya. Apabila dosen memiliki kemampuan sesuai dengan kriteria dosen profesional maka minat belajar mahasiswa akan meningkat, dan apabila dosen tidak memiliki kemampuan yang sesuai dengan kriteria dosen profesional maka minat belajar mahasiswa rendah.

Kondisi belajar mengajar yang efekif adalah adanya minat dan perhatian mahasiswa dalam belajar. Minat belajar seseorang sangat bergantung dan berpengaruh pada dosen. Dosen dalam konteks pendidikan mempunyai peranan penting yang besar dan strategis. Hal ini disebabkan dosenlah yang berada di barisan terdepan dalam pelaksanaan pendidikan. Dosen juga yang langsung berhadapan dengan peserta didik untuk mentransfer ilmu pengetahuan dan teknologi sekaligus mendidik dengan nilai-nilai positif melalui bimbingan dan keteladanan. Uraian di atas menggambarkan bahwa dosen yang profesional sangat erat kaitannya peningkatan minat belajar para mahasiswa, dimana dosen merupakan fasilitator sekaligus mendidik mahasiswa dalam meningkatkan minat belajar mahasiswa sehingga memperoleh prestasi yang memuaskan. Tanpa adanya dosen yang profesional maka mahasiswa akan mengalami kendala dalam meningkatkan minat dalam belajarnya dan otomatis prestasi belajarnya akan menurun.

Selain profesinalisme mengajar hasil penelitian juga menunjukkan bahwa tingkat sosial ekonomi berpengaruh positif terhadap minat mahasiswa. Salah satu yang berkaitan dengan tingkat sosial ekonomi adalah fasilitas belajar mahasiswa. Dapat dikatakan bahwa semakin lengkap fasilitas belajar mahasiswa maka semakin baik minat belajar mahasiswa. Hal ini juga sesuai dengan kesimpulan dari Ramadhan (2008) bahwa upaya orang tua untuk mendorong semangat belajar anaknya adalah dengan melengkapi sarana dan fasilitas belajar mahasiswa, sebab akan membantu anak dalam proses belajar. Dengan demikian profesionalisme mengajar dan tingkat sosial ekonomi berpengaruh positif dalam meningkatkan minat mahasiswa meskipun untuk tingkat sosial pengaruhnya tidak signifikan tetapi tetap berpengaruh positif.

Pada penelitian ini juga ditemukan adanya pengaruh langsung dan signifikan profesionalisme mengajar terhadap hasil belajar mahasiswa, begitu pula tingkat sosial Copyright (C) 2018, Histogram: Jurnal Pendidikan Matematika ISSN: 2549-6700 (print), ISSN 2549-6719 (online) 


\section{Histogram: Jurnal Pendidikan Matematika, 2 (2), 2018 - 143 Rahma Hidayati Darwis}

ekonomi yang juga langsung berpengaruh secara signifikan terhadap hasil belajar. Hal ini sejalan dengan sebuah penelitian yang dilakukan oleh Titin Nuhidayah (2015) yang menyatakan terdapat pengaruh yang positif dan signifikan antara variabel profesionalisme mengajar dengan variabel prestasi belajar pada mata pelajaran.

Peranan profesionalisme mengajar dalam meningkatkan hasil belajar sangat penting. Dalam mewujudkan proses kegiatan pendidikan dan pengajaran, maka unsur yang terpenting antara lain adalah bagaimana dosen dapat merangsang dan mengarahkan mahasiswa dalam belajar, yang pada gilirannya dapat mendorong mahasiswa dalam pencapaian hasil belajar secara optimal. Mengajar dapat merangsang dan membimbing dengan berbagai pendekatan, dimana setiap pendekatan dapat mengarah pada tercapainya tujuan belajar yang berbeda. Tetapi apapun subyeknya mengajar pada hakekatnya adalah menolong mahasiswa dalam memperoleh pengetahuan, keterampilan, sikap dan ide serta apresiasi yang mengarah pada perubahan tingkah laku dan pertumbuhan mahasiswa.

Begitu halnya dengan tingkat sosial ekonomi yang juga berkonstribusi dalam peningkatan hasil belajar. Dalam lingkungan masyarakat kita melihat bahwa ada pembedabedaan yang berlaku dan diterima secara luas oleh masyarakat. Di sekitar kita ada orang yang menempati jabatan tinggi seperti gubernur dan walikota dan jabatan rendah seperti camat dan lurah. Di sekolah ada kepala sekolah dan ada staf sekolah. Di RT atau RW kita ada orang yang tingkat sosial ekonominya tinggi, orang biasa saja dan ada orang yang tingkat sosial ekonominya rendah.

Slameto (2003:65) menjelaskan bahwa keadaan ekonomi keluarga erat hubungannya dengan hasil belajar. Kebutuhan-kebutuhan harus terpenuhi dan hanya dapat terpenuhi jika orang tuanya mempunyai cukup uang. Jika hidup dalam keluarga yang kurang mampu, maka kebutuhan kurang terpenuhi akibatnya kesehatan kurang terganggu sehingga belajar juga terganggu. Akibat yang lain adalah mahasiswa selalu dirundung kesedihan sehingga merasa minder dengan teman lain, ini pasti mengganggu prestasi belajar.

Dari kutipan yang diungkap oleh Slameto jelas memberikan perbandingan gambaran antara mahasiswa yang berada dalam kehidupan orang tua yang cukup mampu secara ekonomi akan mendukung atau mendorong bahkan dapat mengacu prestasi belajar seorang mahasiswa jika dibandingkan dengan mahasiswa yang berada dalam lingkungan keluarga yang kurang mampu. Mahasiswa yang hidup di lingkungan keluarga di mana secara ekonomi orang tuanya dapat memenuhi kebutuhan hidupnya, karena tidak dapatlah Copyright (C) 2018, Histogram: Jurnal Pendidikan Matematika ISSN: 2549-6700 (print), ISSN 2549-6719 (online) 


\section{Histogram: Jurnal Pendidikan Matematika, 2 (2), 2018 - 144 Rahma Hidayati Darwis}

dipungkiri bahwa salah satu yang mendukung kelancaran mahasiswa menghadapi proses belajar adalah apabila terpenuhi kebutuhannya dalam hal ekonomi dalam menunjang hasil belajar. Keberhasilan suatu kegiatan belajar yang dilakukan oleh setiap individu sangat dipengaruhi oleh beberapa faktor sosial ekonomi yang terdiri dari tingkat pendidikan, tingkat pendapatan, jumlah tanggungan dalam keluarga.

Selain kedua faktor eksternal di atas terdapat pula faktor internal yang secara langsung juga mempengaruhi hasil belajar mahasiswa. Hasil analisis sebelumnya menunjukkan bahwa semakin tinggi minat belajar mahasiswa prodi perbankan syariah maka semakin cenderung mahasiswa memperoleh hasil belajar yang memuaskan. Hal ini sesuai dengan pendapat Dalyono (2007:57) bahwa "Minat belajar yang besar cenderung menghasilkan prestasi yang tinggi, sebaliknya minat belajar kurang akan menghasilkan prestasi yang rendah."

Selanjutnya Slameto (2003: 180) mengungkapkan bahwa minat adalah suatu rasa lebih suka dan rasa ketertarikan pada suatu hal atau aktivitas, tanpa ada yang menyuruh. Minat merupakan salah satu hal yang dapat mempengaruhi kualitas hasil belajar mahasiswa dalam mata kuliah tertentu. mahasiswa akan memberikan perhatian yang lebih terhadap mata kuliah tertentu yang mereka minati dibandingkan dengan mata kuliah yang lainnya. Minat yang tinggi terhadap suatu pelajaran tertentu membuat orang lebih bersemangat belajar untuk memperoleh suatu hasil yang baik. Minat juga menjadi sumber motivasi yang kuat dari dalam diri mahasiswa untuk mencapai suatu keberhasilan dalam belajar.

Selanjutnya terkait dengan pengaruh tidak langsung (melalui minat) dalam penelitian ini, diperoleh bahwa minat belajar mahasiswa dapat memperkuat pengaruh profesionalisme mengajar dan tingkat sosial ekonomi terhadap hasil belajar mahasiswa. Artinya pengaruh profesionalisme mengajar dan tingkat sosial ekonomi terhadap hasil belajar mahasiswa STAIN Watampone prodi ekonomi syariah akan semakin kuat jika masing-masing variabel profesionalisme mengajar dan tingkat sosial ekonomi disertai dengan minat belajar yang tinggi.

Berdasarkan hasil temuan penelitian ini, maka diperkirakan bahwa mahasiswa yang tidak memiliki minat belajar yang tinggi atau diajar oleh dosen yang tidak memenuhi memenuhi kriteria profesionalisme, atau tingkat sosial ekonomi rendah akan memiliki tingkat hasil belajar yang kurang. Hal ini didukung dengan hasil data sebelumnya yang menunjukkan bahwa ketiga variabel tersebut berpengaruh positif terhadap hasil belajar statistik inferensial mahasiswa program studi ekonomi syariah. Kenyataan ini sesuai bahwa Copyright (C) 2018, Histogram: Jurnal Pendidikan Matematika ISSN: 2549-6700 (print), ISSN 2549-6719 (online) 


\section{Histogram: Jurnal Pendidikan Matematika, 2 (2), 2018 - 145 \\ Rahma Hidayati Darwis}

profesionalisme mengajar, tingkat sosial ekonomi dan minat belajar sangat penting peranannya dalam peningkatan hasil belajar mahasiswa.

\section{KESIMPULAN DAN SARAN}

\section{A. Kesimpulan}

Dari hasil analisis dan pembahasan yang telah dilakukan, maka dapat ditarik beberapa kesimpulan sebagai berikut:

1. Hasil analisis deskriptif hasil belajar menunjukkan bahwa mahasiswa STAIN Watampone program studi ekonomi syariah dalam ketegori tinggi.

2. Hasil analisis deskriptif profesionalisme mengajar menunjukkan bahwa Dosen mata kuliah yang mengampuh mata kuliah statistik inferensial tergolong dalam kategori tinggi.

3. Hasil analisis deskriptif tingkat sosial ekonomi menunjukkan bahwa orang tua mahasiswa sebagian besar memiliki tingkat sosial ekonomi yang berada pada kategori sedang atau menengah.

4. Hasil analisis deskriptif minat belajar menunjukkan bahwa mahasiswa STAIN Watampone program studi ekonomi syariah memiliki minat belajar yang tergolong tinggi

5. Terdapat pengaruh secara langsung profesionalisme mengajar maupun tingkat sosial ekonomi terhadap hasil belajar.

6. Persamaan regresi $X_{3}=0,412 X_{1}+0,422 X_{2}+e 1$ dan $R^{2}=0,414$ menunjukkan bahwa sekitar 41,4\% variansi minat belajar mahasiswa dapat dijelaskan oleh profesionalisme mengajar dan tingkat sosial ekonomi secara bersama-sama. Sehingga masih ada 58,6\% variansi minat belajar mahasiswa yang dijelaskan oleh faktor-faktor lain yang tidak ikut diselidiki dalam penelitian ini.

7. Persamaan regresi $\mathrm{Y}=0,335 X_{1}+0,078 X_{2}+0,694 X_{3}+e 2$ dan $R^{2}=0,268$ menunjukkan bahwa sekitar 26,8\% variansi hasil belajar mahasiswa pada mata kuliah statistik dapat dijelaskan oleh profesionalisme mengajar, tingkat sosial ekonomi dan minat belajar secara bersama-sama. Sehingga masih ada 73,2\% varians hasil belajar mahasiswa yang dijelaskan oleh faktor-faktor lain yang tidak ikut diselidiki dalam penelitian ini

8. Minat belajar mahasiswa dapat memperkuat pengaruh profesionalisme mengajar dan tingkat sosial ekonomi dalam meningkatkan hasil belajar. Atau dengan kata lain 
Histogram: Jurnal Pendidikan Matematika, 2 (2), 2018 - 146

Rahma Hidayati Darwis

konstribusi profesionalisme mengajar dan tingkat sosial ekonomi terhadap hasil belajar mahasiswa STAIN Watampone prodi ekonomi syariah akan semakin besar jika masing-masing variabel profesionalisme mengajar dan tingkat sosial ekonomi disertai dengan minat belajar yang tinggi.

\section{B. Saran}

Berdasarkan hasil penelitian dan pembahasan serta kesimpulan yang telah dikemukakan di atas, maka dapat disarankan beberapa hal sebagai berikut:

1. Untuk mempertahankan dan meningkatkan hasil belajar dosen sebagai fasilitator dalam belajar diharapkan mampu menguasai kompetensi pembelajaran yang menjadi indikator profesionalisme mengajar.

2. Variabel dalam penelitian ini difokuskan pada dua faktor eksternal dan satu faktor internal dari diri mahasiswa, untuk mengkaji lebih mendalam lagi ada baiknya dilakukan penelitian lanjutan yang variabelnya melibatkan beberapa faktor internal dan eksternal dari diri mahasiswa. 


\section{DAFTAR PUSTAKA}

Dalyono. (2007). Hubungan Minat Menjadi Guru Dan Profesionalisme Guru Dengan Prestasi Belajar Micro Teaching Pada Mahasiswa Program Studi Pendidikan Ekonomi. Tesis Pascasarjana UNS. Tidak diterbitkan.

Departemen Pendidikan Nasional. (2003). Undang-Undang Nomor 20 Tahun 2003, Tentang Sistem Pendidikan Nasional, Jakarta: Depdiknas

Departemen Pendidikan Nasional. (2005). Undang-Undang Nomor 14 Tahun 2005, Tentang Guru dan Dosen, Jakarta: Depdiknas.

Fitriyani, T. (2015). Pengaruh Metode Pembelajaran Terhadap Hasil Belajar Ditinjau Dari Tingkat Ekonomi Keluarga. Tesis Pascasarjana UNS. Tidak diterbitkan.

Prasetya. (2001). Metode Role Playing Untuk Meningkatkan Hasil Belajar Siswa kelas II SLTP N 3 Driyono Gresik. Buletin Pelangi Pendidikan. Edisi IV Tahun II

Ramadhan. (2008). Pengaruh Media Pembelajaran Lcd Proyektor dan Minat Belajar dengan Hasil Belajar Mata Pelajaran Keselamatan dan Kesehatan Kerja (K3) Siswa Kelas X Teknik Gambar Bangunan SMK Negeri 4 Sukoharjo. Tesis Pascasarjana UNS. Tidak diterbitkan

Slameto. (2003). Belajar dan Faktor-Faktor yang Mempengaruhinya. Jakarta: PT.Rineka Cipta.

Sudjana, N. (2001). Penelitian dan Penilaian Pendidikan. Bandung: Sinar Baru 